\title{
Self-Medication for Dysmenorrhea Among Serbian Medical Students
}

\author{
Mia S. Manojlović ${ }^{1,2}$, Ana D. Tomas ${ }^{3}$, Milica M. Paut Kusturica ${ }^{3}$, \\ Veljko S. Ćućuz ${ }^{4}$ Ivor S. Kolarski ${ }^{2,5}$, Dragana D. Zaklan ${ }^{6}$, \\ Kristina M. Stepanović ${ }^{1,2}$, Olga J. Horvat ${ }^{3}$ \\ ${ }^{1}$ Clinic for Endocrinology, Diabetes and Metabolic Disorders, Clinical Center of Vojvodina, \\ Novi Sad, Serbia \\ ${ }^{2}$ Faculty of Medicine, University of Novi Sad, Novi Sad, Serbia \\ ${ }^{3}$ Department of Pharmacology, Toxicology and Clinical Pharmacology, Faculty of Medicine, \\ University of Novi Sad, Novi Sad, Serbia \\ ${ }^{4}$ Department of Biomedical Sciences, College of Vocational Studies for the Education of Pre- \\ school Teachers and Sport Trainers, Subotica, Serbia \\ ${ }^{5}$ Center for Forensic Medicine, Toxicology and Molecular Genetics, Clinical Center of Vojvo- \\ dina, Novi Sad, Serbia \\ ${ }^{6}$ Department of Pharmacy, Faculty of Medicine, University of Novi Sad, Novi Sad, Serbia
}

\section{SUMMARY}

Introduction: Primary dysmenorrhea is a common disorder in women, with a significant impact on quality of life.

Aim: The objective of this academic study was to investigate the severity of dysmenorrhea in female students of the Faculty of Medicine in Novi Sad, to estimate the self-medication prevalence of primary dysmenorrhea, to identify the most commonly used conventional, herbal, homeopathic remedies and manner of their usage, as well as non-pharmacological measures in the treatment of primary dysmenorrhea.

Material and Methods: This study was performed on a random sample of 100 respondents from different departments of the Faculty of Medicine in Novi Sad, from December $1^{\text {st }}$ to December $15^{\text {th }}, 2016$. The data were obtained by using a standardized questionnaire.

Results: The sample included 59 female medical students and 41 female students of the other study groups. Most of the respondents had medium expressed symptoms due to dysmenorrhea (48.0\%). The most common symptoms were cramps and pain in the lower abdomen, anxiety, and appetite changes. $11 \%$ of respondents were absent from classes at the university minimum one day of each menstrual cycle, because of dysmenorrhea. $66 \%$ of respondents used drugs due to symptoms of dysmenorrhea. The most commonly used group of drugs were non-steroid anti-inflammatory drugs (75.76\%), primarily ibuprofen (53.03\%), and diclofenac (10.61\%). Self-medication prevalence was $48.48 \%$.

Conclusion: According to the results of this study, dysmenorrhea symptoms significantly impact the quality of life.

Keywords: Menstrual Pain, Non-Steroid Anti-Inflammatory Drugs, Medical Students 


\section{INTRODUCTION}

Primary dysmenorrhea is defined as painful menstruation, which occurs after the onset of menarche and after establishing ovulatory menstrual cycles, in the absence of pathological findings on the genital organs. According to the literature, the prevalence of primary dysmenorrhea is $50-70 \%$ within the adolescent population [1]. Primary dysmenorrhea is a consequence of increased concentrations of prostaglandins (PGs) released from the endometrium. PGs cause increased contractility of the myometrium, which leads to ischemia and consequent pain. PGs also affect the contractility of the gastrointestinal tract smooth muscles and the increased sensitivity of peripheral nerves [2].

Primary dysmenorrhea usually occurs in younger women, but rarely with the first menstruation, similarly the fact that the first cycles are anovulatory $[1,2,3,4]$. The pain can vary in intensity and duration. Some women can have only minor symptoms during menstruation, while for some, the pain can be so intense that it makes woman incapable of any activity. In general, condition can be manifested by headache, dizziness, nausea, vomiting, diarrhea, changes in appetite, weakness, and psychological manifestations (hypersensitivity, crying, irritability, anxiety, mood changes) $[5,6]$.

Treatment is aimed at reducing the concentration of PGs in the endometrium as well as reducing the sensitivity of the receptors, primarily with non-steroid anti-inflammatory drugs (NSAIDs). Acetylsalicylic acid, ibuprofen and diclofenac are most commonly used substances, mainly in the form of oral drugs or suppositories $[7,8]$. However, in about $15 \%$ of women of different ages, with dysmenorrhea, an appropriate therapeutic response is not achieved after using NSAIDs, thus they use contraceptive hormonal therapy as the second therapy line. Contraceptive hormonal therapy reduces endometrial thickness, so menstruation becomes shorter, sparser and less painful. Other analgesics, as well as antispasmodics, are also used in the therapy of dysmenorrhea, but with less success. However, despite various therapeutic modalities, the symptoms often persist, so the influence of psychogenic factors on the development of pain should not be excluded $[6,9,10,11,12,13,14,15]$.

Primary dysmenorrhea is the most common reason for absence from work and classes among young women and adolescents [10]. The use of drugs due to dysmenorrhea has been identified as one of the most common forms of self-medication with analgesics among Serbian students, second only to headache [11]. There is no data available on the frequency of dysmenorrhea, severity of symptoms, or the management of this disorder in Serbia.

\section{AIM}

The objective of this study was to investigate the severity of dysmenorrhea, estimate the self-medication prevalence of primary dysmenorrhea, identify the most commonly used conventional, herbal, homeopathic remedies and manner of their usage, as well as nonpharmacological measures in the treatment of primary dysmenorrhea among the student population.

\section{MATERIAL AND METHODS}

This academic study was conducted on a random sample of 100 students from different study groups of the Faculty of Medicine in Novi Sad, who attended General pharmacology classes at the Department of Pharmacology, Toxicology, and Clinical Pharmacology. The respondents filled in the questionnaire before starting the practical classes. The research was conducted in a period from December $1^{\text {st }}$ to December $15^{\text {th }}, 2016$. The study was approved by the Ethics Committee of the Faculty of Medicine in Novi Sad (approval number: $01-39 / 82 / 1$ ), as academic (non-commercial) study. Before completing the questionnaire, all respondents were informed of the study's details and signed the informed consent.

The questionnaire contained questions about the severity of dysmenorrhea (13 questions), medication due to dysmenorrhea symptoms (12 questions), the use of nonpharmacological methods to relieve these symptoms (1 question), and general data (7 questions). The score of dysmenorrhea was calculated based on the first 13 questions. The dysmenorrhea score was calculated based on the answers to the following closed-ended questions: How often do you miss lectures at college or work due to dysmenorrhea prob- 
lems? (0.2-1 points); Have the symptoms of dysmenorrhea in the past year required you to seek help and go to the doctor? (0.1); Intensity of dysmenorrhea symptoms (cramps and pain in the lower abdomen, nervousness, changes in appetite, back pain, malaise, headache, diarrhea, nausea, dizziness, vomiting) - for each symptom using the Likert scale, the following intensity: Asymptomatic ( 0.2 points), Mild (0.4), Moderate (0.6), Severe (0.8), Unbearable (1.0), was assigned, so that the 10 listed symptoms carried a total of 1-10 points, pain intensity on a scale of $0-10$ (0-1 points). The minimum score was therefore 1.4 and the maximum 13. Respondents were divided into three groups depending on the score of dysmenorrhea - mild symptoms (score less than 5), moderate symptoms (score 5.1-9), and very severe symptoms (score $>9.1$ ). Then followed the questions about taking drugs - the first YES / NO question was about taking drugs in the past 3 months due to dysmenorrhea. Respondents who answered they were taking drugs, further answered the question which drug they took most often in the past 3 months due to dysmenorrhea; on whose recommendation they took this drug; whether they read the patient information leaflet; in what dose, form and in what way they administer the drug; how many days in a row did they take these drugs the last time they used it ( 1 day, 2-3 days, $\geq 4$ days); whether they experienced any side effects while taking the drug (if they answered yes, in the next question they were asked to list the side effects they experienced). All respondents also answered questions whether they took any herbal remedies in addition to conventional drugs (if they answered yes, in the next question, they were asked to state which herbal remedies they took) and whether they applied some of the non-pharmacological methods (rest, showering with hot water, warming, exercise, change of diet, other - add). The third part of the questionnaire referred to general data (year of birth, height, body weight, age at first menstruation, the usual duration of menstrual bleeding, the usual duration of the menstrual cycle, number of births, study program, year of study). For the drugs listed by the respondents, an international non-proprietary name was identified, and the drugs were classified according to the Anatomical Therapeutic Chemical (ATC) Classification System and divided into three groups (NSAIDs, analgesics, antispasmodics).
The data was processed in Excel 2016 and Statistical Package for the Social Sciences (SPSS) software (IBM SPSS Statistics, V22.0). Out of the measures of central tendency, the arithmetic mean was used, and the measure of variation was expressed by the standard deviation. The statistical significance of the differences determined between the groups was examined by one-way analysis of variance (ANOVA) with Tukey post hoc test. The $\chi$-square test was used for frequency data. Statistical hypotheses were tested at the level of statistical significance (alpha level) of 0.05 . The results are presented in form of tables and figures.

\section{RESULTS}

The sample included 59 female medical students and 41 female students from other study groups. The mean value of dysmenorrhea score was $5.62 \pm 2.02$ (range $1.6-10.8$ ) from the maximum of 13 . The largest number of students was in the physiological range regarding Body Mass Index (BMI) and the duration and frequency of menstrual cycles: BMI within the physiological range, age at first menstruation 12-14 years, average menstrual cycle duration 22-30 days, and normal menstrual bleeding duration 3-7 days. The frequency of severe dysmenorrhea symptoms was significantly higher in female students with cycles shorter than 21 days. For other parameters, no statistically significant differences were observed in the frequency of different degrees of severity of dysmenorrhea using the $\chi^{2}$ test (Table 1 ).

As Table 2 shows, the most common dysmenorrhea symptoms were cramps and pain in the lower abdomen, nervousness and changes in appetite. The mean pain intensity accompanying dysmenorrhea was $5.7 \pm 2.8$ (range 0-10).

As many as $11 \%$ of respondents missed classes for at least one day of each cycle, and an even higher percentage occasionally missed classes due to dysmenorrhea (16\%, 3-4 times a year). The most significant number of respondents had moderate $(48.0 \%)$ and mild dysmenorrhea symptoms (45.0\%), and only $7.0 \%$ of respondents had very severe symptoms, which is shown in Figure 1.

The need to see a doctor due to dysmenorrhea statistically significantly differed, depending on the severity of symptoms ( $\chi 2$ (2, $\mathrm{N}=100)=22.38, \mathrm{p}<0.001)$. In the past year, 


\begin{tabular}{|c|c|c|c|c|c|}
\hline Parameter & $\begin{array}{c}\text { Mild } \\
\text { symptoms }\end{array}$ & $\begin{array}{l}\text { Moderate } \\
\text { symptoms }\end{array}$ & $\begin{array}{c}\text { Severe } \\
\text { symptoms }\end{array}$ & Total & p value \\
\hline \multicolumn{6}{|l|}{ BMI status } \\
\hline < 18.5 (underweight) & $6(13.3 \%)$ & $7(14.6 \%)$ & $1(14.3 \%)$ & 14 & \multirow{5}{*}{$p=0.675$} \\
\hline 18.6-24.9 (normal weight) & $35(77.8 \%)$ & $34(70.8 \%)$ & $6(85.7 \%)$ & 75 & \\
\hline 25-29.9 (overweight) & $0(0.0 \%)$ & $3(6.3 \%)$ & $0(0.0 \%)$ & 3 & \\
\hline >30 (obesity) & $0(0.0 \%)$ & $1(2.1 \%)$ & $0(0.0 \%)$ & 1 & \\
\hline I don't want to answer & $4(8.9 \%)$ & $3(6.3 \%)$ & $0(0.0 \%)$ & 7 & \\
\hline \multicolumn{5}{|l|}{ Menstrual cycle duration } & \multirow{5}{*}{$p=0.021$} \\
\hline$<21$ days & $2(4.4 \%)$ & $1(2.1 \%)$ & $1(14.3 \%)$ & 4 & \\
\hline > 31 days & $12(26.7 \%)$ & $13(27.1 \%)$ & $1(14.3 \%)$ & 26 & \\
\hline 22-30 days & $29(64.4 \%)$ & $32(66.7 \%)$ & $5(71.4 \%)$ & 66 & \\
\hline I don't want to answer & $2(4.4 \%)$ & $2(4.2 \%)$ & $0(0.0 \%)$ & 4 & \\
\hline \multicolumn{6}{|l|}{ Menstrual bleeding duration } \\
\hline$\leq 2$ days & $0(0.0 \%)$ & $0(0.0 \%)$ & $1(14.3 \%)$ & 1 & \multirow{4}{*}{$p=0.072$} \\
\hline$\geq 8$ days & $1(2.2 \%)$ & $0(0.0 \%)$ & $0(0.0 \%)$ & 1 & \\
\hline 3-7 days & $43(95.6 \%)$ & $48(100.0 \%)$ & $6(85.7 \%)$ & 97 & \\
\hline I don't want to answer & $1(2.2 \%)$ & $0(0.0 \%)$ & $0(0.0 \%)$ & 1 & \\
\hline \multicolumn{5}{|l|}{ The age at menarche } & \multirow{5}{*}{$p=0.475$} \\
\hline$\leq 11$ years & $4(8.9 \%)$ & $9(18.8 \%)$ & $1(14.3 \%)$ & 14 & \\
\hline$\geq 14$ years & $4(8.9 \%)$ & $5(10.4 \%)$ & $1(14.3 \%)$ & 10 & \\
\hline $12-14$ years & $36(80.0 \%)$ & $34(70.8 \%)$ & $5(71.4 \%)$ & 75 & \\
\hline I don't want to answer & $1(2.2 \%)$ & $0(0.0 \%)$ & $0(0.0 \%)$ & 1 & \\
\hline \multicolumn{6}{|c|}{ Contraceptive hormonal therapy } \\
\hline Yes & $3(6.7 \%)$ & $7(14.6 \%)$ & $1(14.3 \%)$ & 11 & \multirow{4}{*}{$p=0.704$} \\
\hline No & $31(68.9 \%)$ & $30(62.5 \%)$ & $5(71.4 \%)$ & 66 & \\
\hline I don't want to answer & $11(24.4 \%)$ & $11(22.9 \%)$ & $1(14.3 \%)$ & 23 & \\
\hline Total & 45 (100.0\%) & $48(100.0 \%)$ & $7(100.0 \%)$ & 100 & \\
\hline
\end{tabular}

no respondents in the group with mild symptoms sought medical help, while in the group with moderate and very severe symptoms as many as $22.9 \%$ and $55.6 \%$ of respondents, respectively, consulted a physician due to dysmenorrhea.

Majority of respondents (66.0\%) took drugs due to dysmenorrhea. The chi-square test showed statistically significant differences $\left(\chi^{2}(2, \mathrm{~N}=100)=28.58, \mathrm{p}<0.001\right)$ in the frequency of medication due to dysmenorrhea, depending on the severity of dysmenorrhea symptoms. In the group of female students who had mild symptoms, $37.2 \%$ of respondents took drugs in the past 3 months, compared to $84.0 \%$ of female students with moderate symptoms and $100 \%$ of subjects with severe dysmenorrhea.

Almost half $(48.48 \%)$ of the respondents used the drug for 2-3 days, while the other half (48.48\%) did it for 1 day. Only $3 \%$
Table 1. Influence of respondents characteristics on dysmenorrhea symptoms severity

\begin{tabular}{l|l|}
\hline \multicolumn{1}{|c|}{ Symptom } & (intensity $0-5)$ \\
\hline $\begin{array}{l}\text { Cramps and pain in the } \\
\text { lower abdomen }\end{array}$ & $3.37 \pm 0.99(0-5)$ \\
\hline Nervousness & $3.11 \pm 1.18(0-5)$ \\
\hline Changes in appetite & $2.89 \pm 1.10(0-5)$ \\
\hline Back pain & $2.64 \pm 1.28(0-5)$ \\
\hline Malaise & $2.24 \pm 1.21(0-5)$ \\
\hline Headache & $2.04 \pm 1.15(0-5)$ \\
\hline Diarrhea & $1.85 \pm 1.23(0-5)$ \\
\hline Nausea & $1.68 \pm 1.02(0-5)$ \\
\hline Dizziness & $1.58 \pm 1.03(0-5)$ \\
\hline Vomiting & $1.24 \pm 0.70(0-5)$ \\
\hline Pain intensity & $5.7 \pm 2.8(0-10)$ \\
\hline
\end{tabular}

of respondents were taking the drug for more than 4 days. There is a statistically significant difference in the dysmenorrhea score depending on duration of medication $(\mathrm{F}=5.20, \mathrm{p}=$ $0.002)$. The dysmenorrhea score was statisti-
Table 2. Intensity of primary dysmenorrhea symptoms 
Figure 1. Share of respondents with different severity of dysmenorrhea symptoms

Table 3. The structure of the drugs used due to dysmenorrhea symptoms

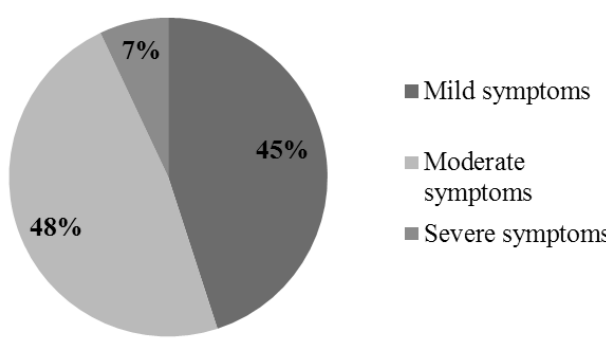

cally significantly higher in the group that took the drug for $2-3$ days $(5.65 \pm 1.08)$ than in the group that took the drug for 1 day $(7.1 \pm 1.77)$, $\mathrm{p}=0.006$.

The most commonly used group of drugs were NSAIDs (75.76\%), and the most

\begin{tabular}{|l|l|c|}
\hline \multicolumn{1}{|c|}{ Drug } & \multicolumn{1}{|c|}{$\mathrm{n}$} & \multicolumn{1}{c|}{$\%$} \\
\hline NSAIDs & 50 & $75.76 \%$ \\
\hline dexketoprofen & 1 & $1.52 \%$ \\
\hline diclofenac & 7 & $10.61 \%$ \\
\hline ibuprofen & 35 & $53.03 \%$ \\
\hline ketoprofen & 3 & $4.54 \%$ \\
\hline naproxen & 3 & $4.54 \%$ \\
\hline nimesulide & 1 & $1.52 \%$ \\
\hline ANALGESICS & 12 & $18.18 \%$ \\
\hline metamizole & 2 & $3.03 \%$ \\
\hline paracetamol & 5 & $7.57 \%$ \\
\hline $\begin{array}{l}\text { paracetamol, caffeine, } \\
\text { codeine, propifenazone }\end{array}$ & 4 & $6.06 \%$ \\
\hline $\begin{array}{l}\text { paracetamol, ropifena- } \\
\text { zone, caffeine }\end{array}$ & 1 & $1.52 \%$ \\
\hline SPAZMOLITICS & 4 & $6.06 \%$ \\
\hline Hyoscine butylbromide & 4 & $6.06 \%$ \\
\hline Total & 66 & $100.00 \%$ \\
\hline
\end{tabular}

commonly used NSAIDs were ibuprofen (53.03\%) and diclofenac (10.61\%), as can be seen in Table 3. About one-fifth of the respondents most often took analgesics (18.18\%), primarily paracetamol and combinations of paracetamol (14.16\%), and only 3\% took metamizole. The use of antispasmodics, i.e. hyoscine butylbromide, was also observed in $6.06 \%$ of subjects (Table 3 ). There were no statistically significant differences in preference of a specific group of drugs depending on dysmenorrhea score $(\chi 2(2, \mathrm{~N}=66)=1.174, \mathrm{p}=$ 0.882).

Figure 2 shows that the respondents most often took medication according to their own assessment (48.48\%), on the recommendation of a gynecologist (19.70\%), and the recommendation of a friend or family member (16.67\%).

The drugs were taken in the form of tablets and capsules; the use of other pharmaceutical forms was not noticed. Most of the respondents read the patient information leaflet before taking medicine (71.21\%), but as many as $59.10 \%$ of the respondents could not correctly state the dose of the medicine they were taking in milligrams, but answered this question with „I do not know” or stated the dose in number of tablets. While taking the medication, 3 subjects experienced side effects, subjects who took ibuprofen experienced gastrointestinal problems (stomach cramps, vomiting), and headache and sleepiness were experienced by one subject who was taking metamizole. In addition to conventional medicines, the use of herbal and homeopathic remedies was recorded in $8 \%$ of respondents - the largest number used teas $(4,4.0 \%)$ and Femisan $\mathrm{A}^{\oplus}$ drops $(3,3.0 \%)$.
Figure 2. The method of choosing the drug used due to the symptoms of dysmenorrhea

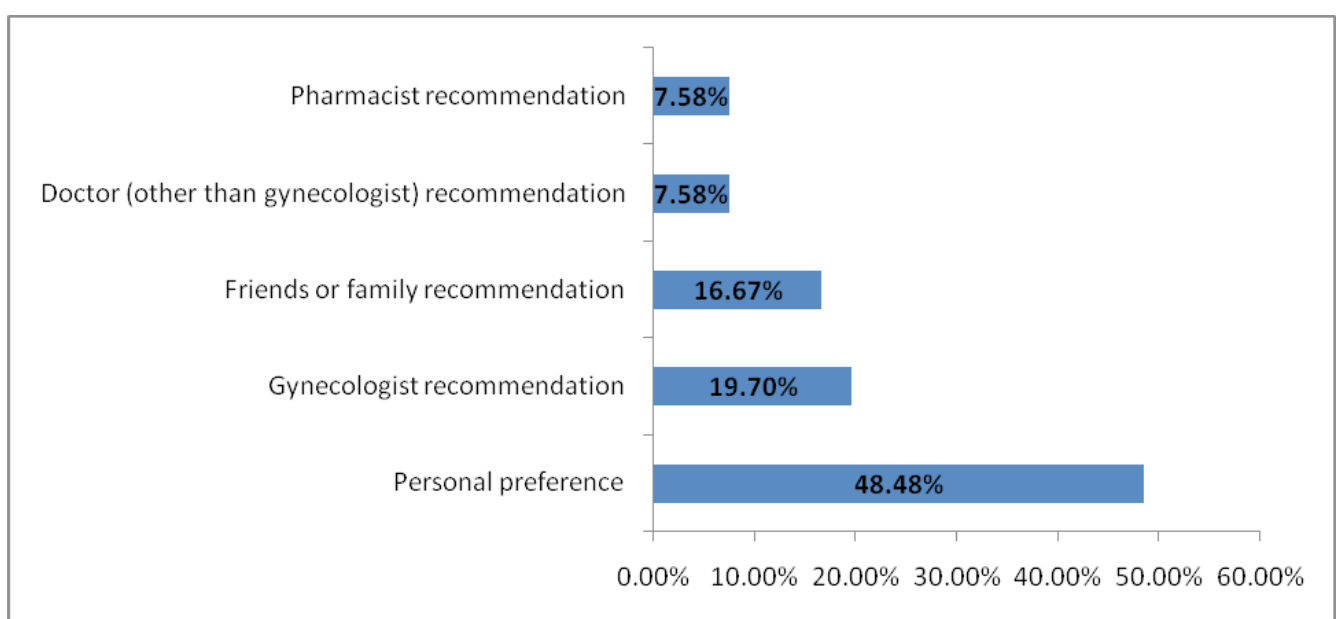




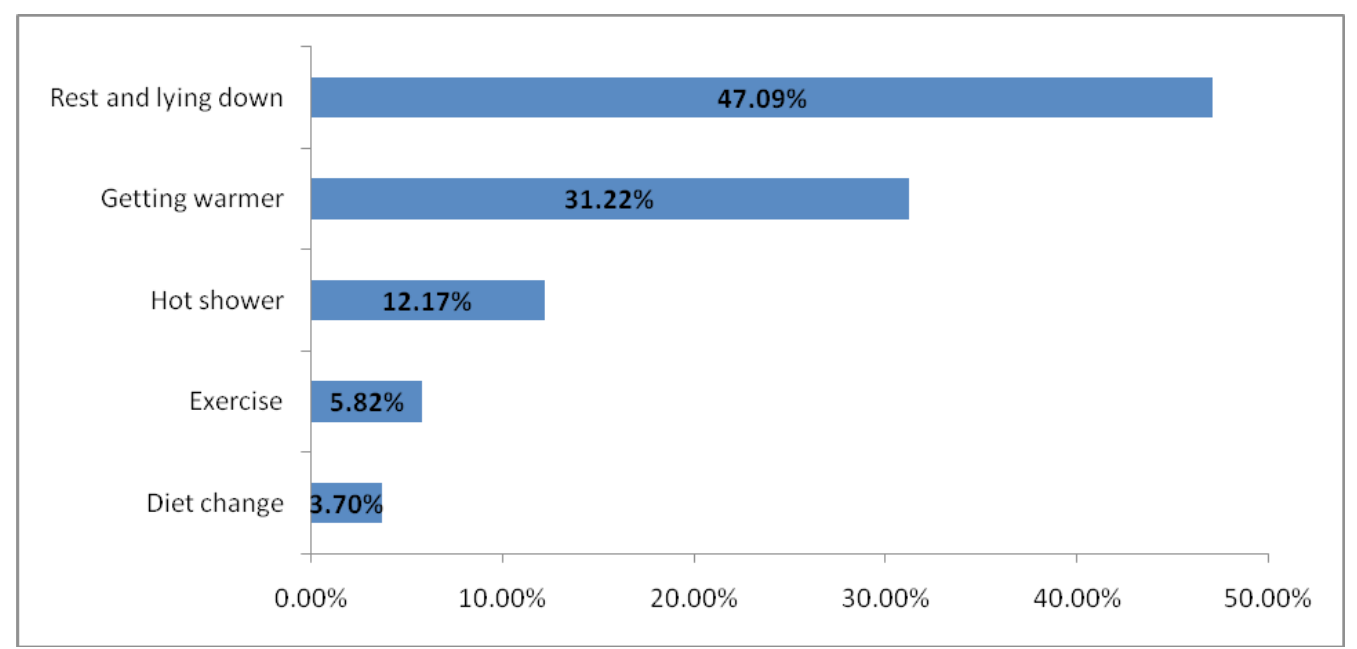

Figure 3. Other methods of self-care for relieving the symptoms of dysmenorrhea

Figure 3 shows an overview of other methods used by the respondents, in order to relieve the symptoms of dysmenorrhea, where $47 \%$ of them chose resting and lying, and round $43 \%$ decided to apply different warming methods.

\section{DISCUSSION}

The prevalence of primary dysmenorrhea is still difficult to determine precisely and is considered to be poorly assessed. Given that many women consider pain during menstruation as an integral part of the menstrual cycle rather than as a disorder, many cases go unnoticed. Despite these limitations, dysmenorrhea is considered the most common gynecological disorder regardless of age and nationality. Most women describe the symptoms as mild or moderate, while very severe dysmenorrhea occurs in $10 \%$ of cases, which is close to the results of this study, where the score of dysmenorrhea identified $7 \%$ of respondents with very severe dysmenorrhea [2]. The symptoms that the respondents state as most pronounced, along with lower abdominal pain and cramps, vary in intensity and frequency from study to study, and include nausea and vomiting, diarrhea, headache, dizziness and changes in appetite, while in our study, nervousness stands out $[6,12]$. In the United States of America (USA), it is estimated that primary dysmenorrhea is responsible for the loss of 600 million working hours and 2 billion dollars a year [2]. Similar research was conducted in Europe, so according to data from Sweden, the loss of 230,000 working days is attributed to dysmenorrhea problems. The impact of dysmenorrhea on the quality of life of the respondents in our study is indisputable, because due to dysmenorrhea as many as $11 \%$ of respondents missed classes at the Faculty for at least one day of each cycle $[2,6,13]$.

It is essential to pay attention to the quality of social interaction that respondents have during menstruation. The literature shows that the prevalence of anxiety, agitation and depressed mood increases significantly during these days, which is close to the abovementioned nervousness $[9,10]$.

The study results, which aimed to analyze the usage of drugs for the treatment of primary dysmenorrhea in adolescents, show that $70 \%$ of respondents used over-thecounter (OTC) drugs, and $57 \%$ of adolescents underwent inadequate dosing regimens. Likewise, a study that involved 2699 adolescent girls showed that only $29 \%$ of respondents described their problems as very severe and sought medical advice $[6,9,10,11,12,13,14,15]$.

Drugs were used by $66 \%$ of respondents due to dysmenorrhea, which is slightly lower than in a similar study conducted on almost the same sample size, in the United States, where drug use reaches $93 \%$ [6]. The frequency of taking the medication and the duration of use depended on the severity of the symptoms of dysmenorrhea, as shown in the results. Thus, $84 \%$ of female students with moderate symptoms and $100 \%$ of respondents with very severe dysmenorrhea symptoms reported the use of at least one drug. The most commonly used drugs belong to the NSAIDs group, which supports the data that this group of drugs leads to pain cessation in $64-100 \%$ of women with dysmenorrhea $[1,2]$. The most 
frequently used drugs from this group were ibuprofen (53\%) and diclofenac (10\%). In other similar studies, ibuprofen leads in the frequency of use, which is above $50 \%$, and diclofenac is stated to be particularly effective, not only for relieving menstrual pain during rest, but also for relieving pain during physical activity and sleep $[2,5]$. The use of paracetamol is significantly lower than in other similar studies, which is important because it has been proven that it does not affect the pain of this etiology [6]. Also, it is important to say that, as in other studies, the use of metamizole is relatively low, similar to the fact that it is from the analgesics group and carries the risk of agranulocytosis [12].

Based on our study results, half of the respondents most often took medication according to their assessment (48\%). It has been proven that there is a statistically significantly higher frequency of self-medication in medical students than in students of other disciplines $[11,12]$. The most commonly used drugs, namely ibuprofen and diclofenac, with issuance according to the respondents' dosage regimen, belong to the group of prescription drugs in Serbia. However, they are OTC, which can be reflected in irrational use, because more than half of the respondents in our study could not correctly state the dose of the drug (in milligrams) they took. It is important to mention that according to the available data, in respondents who describe their problems as very severe, there is often a lack of therapeutic response, especially if we take into consideration the inadequate dosage regimen, which respondents in our study were prone to. Also, it is important to note that NSAIDs' use carries the risk of side effects, which is not high in the case of short-term use, but cannot be ignored [16].

The non-pharmacological treatment of dysmenorrhea coincided with the results of other studies and included resting (as many as half of the respondents), heating and showering with hot water. Heating is significant in terms of efficacy, as the controlled study showed that continuous moderate heating is as effective as ibuprofen and even more effective than paracetamol [17]. Regarding herbal preparations, the use of Femisan $A^{\oplus}$ was noted, which efficacy data is not available in the literature. These herbal drops contain Lady's Mantle, yarrow, parsley, marigold, herb-Robert (red robin) and knotgrass. Re- cent meta-analysis showed that some herbal medicines like ginger, cinnamon and fennel reduce dysmenorrhea severity, primarily pain intensity, as well as pain duration [18]. Also, a double-blind, randomized, placebo-controlled trial indicates higher efficacy of homeopathic medicines in the treatment of dysmenorrhea compared to placebo [19].

\section{CONCLUSION}

This study showed that self-medication is very common in the treatment of primary dysmenorrhea in female students of the Faculty of Medicine in Novi Sad, although knowledge about drug selection and adequate dosing is scarce. In the light of the prevalence of primary dysmenorrhea in the general population, education programs for adolescents and young women on this topic are necessary, as well as the possibility of considering the problem when visiting a general practitioner or gynecologist. Also, there is need for more extensive research on the impact of dysmenorrhea on quality of life, having in mind long-term manifestations of the disorder and predisposition for the development of chronic pain.

\section{CONFLICTS OF INTEREST}

All authors declare no conflict of interest.

\section{REFERENCES}

1. Guimarães I, Póvoa AM. Primary Dysmenorrhea: Assessment and Treatment. Rev Bras Ginecol Obstet. 2020 Aug;42(8):501-507.

2. lacovides S, Avidon I, Baker FC. What we know about primary dysmenorrhea today: a critical review. Hum Reprod Update. 2015;21(6):762-778.

3. Habibi N, Huang MSL, Gan WY, Zulida R, Safavi SM. Prevalence of Primary Dysmenorrhea and Factors Associated with Its Intensity Among Undergraduate Students: A Cross-Sectional Study. Pain Manag Nurs. 2015;16(6):855-61.

4. Grandi G, Ferrari S, Xholli A, Cannoletta M, Palma F, Romani $C$, et al. Prevalence of menstrual pain in young women: what is dysmenorrhea? J Pain Res. 2012 Jun;5:169-74.

5. Ferries-Rowe E, Corey E, Archer JS. Primary Dysmenorrhea: Diagnosis and Therapy. Obstet Gynecol. 2020 Nov;136(5):1047-1058.

6. O'Connell K, Davis AR, Westhoff C. Self-treatment Patterns Among Adolescent Girls with Dysmenorrhea. J Pediatr Adolesc Gynecol. 2006;19(4):285-9. 
7. Durain D. Primary dysmenorrhea: assessment and management update. J Midwifery Womens Health. 2004 Nov;49(6):520-8.

8. Dawood MY. Primary dysmenorrhea: advances in pathogenesis and management. Obstet Gynecol. 2006 Aug;108(2):428-41.

9. Campbell MA, McGrath PJ. Use of medication by adolescents for the management of menstrual discomfort. Arch Pediatr Adolesc Med. 1997 Sep;151(9):905-13. doi: 10.1001/archpedi.1997.02170460043007. PMID: 9308868.

10. Johnson J. Level of knowledge among adolescent girls regarding effective treatment for dysmenorrhea. J Adolesc Health Care. 1988;9(5):398-402.

11. Brlić KČ, Janev Holcer N, Sović S, Štimac D. Characteristics of self-medication for pain relief among first-year health care students in Zagreb, Croatia. Psychiatr Danub. 2014 Dec;26 Suppl 3:45965.

12. Sugumar R, Krishnaiah V, Channaveera GS, Mruthyunjaya $S$. Comparison of the pattern, efficacy, and tolerability of self-medicated drugs in primary dysmenorrhea: a questionnaire based survey. Indian J Pharmacol. 2013 Mar-Apr;45(2):180-3.

13.Banikarim C, Chacko MR, Kelder SH. Prevalence and impact of dysmenorrhea on Hispanic female adolescents. Arch Pediatr Adolesc Med. 2000 Dec;154(12):1226-9.

14. lacovides S, Baker FC, Avidon I, Bentley A. Women with dysmenorrhea are hypersensitive to experimental deep muscle pain across the menstrual cycle. J Pain. 2013 Oct;14(10): 1066-76.

15. Bajalan Z, Moafi F, Moradi Baglooei M, Alimoradi Z. Mental health and primary dysmenorrhea: a systematic review. J Psychosom Obstet Gynaecol. 2019 Sep;40(3):185-194.

16. Ortiz MI. Primary dysmenorrhea among Mexican university students: prevalence, impact and treatment. Eur J Obstet Gynecol Reprod Biol. 2010 Sep;152(1): 73-7.

17. Akin MD, Weingand KW, Hengehold DA, Goodale MB, Hinkle RT, Smith RP. Continuous low-level topical heat in the treatment of dysmenorrhea. Obstet Gynecol. 2001 Mar;97(3):343-9.

18. Xu Y, Yang Q, Wang X. Efficacy of herbal medicine (cinnamon/fennel/ginger) for primary dysmenorrhea: a systematic review and metaanalysis of randomized controlled trials. J Int Med Res. 2020 Jun;48(6):300060520936179. doi: 10.1177/0300060520936179. PMID: 32603204; PMCID: PMC7328489.

19. Ghosh S, Ravindra RK, Modak A, Maiti S, Nath A, Koley M, Saha S. Efficacy of individualized homeopathic medicines in primary dysmenorrhea: a double-blind, randomized, placebo-controlled, clinical trial. J Complement Integr Med. 2021 Jun 3. doi: $10.1515 /$ jcim-2020-0512. Epub ahead of print.
PMID: 34085495. 


\title{
Samomedikacija primarne dismenoreje kod studentkinja medicine u Srbiji
}

\author{
Mia S. Manojlović, ${ }^{1,2}$, Ana D. Tomas ${ }^{3}$, Milica M. Paut Kusturica ${ }^{3}$, Veljko S. Ćućuz ${ }^{4}$, \\ Ivor S. Kolarski ${ }^{2,5}$, Dragana D. Zaklan ${ }^{6}$, Kristina M. Stepanović, ${ }^{1,2}$, Olga J. Horvat ${ }^{3}$ \\ ${ }^{1}$ Klinika za endokrinologiju, dijabetes i bolesti metabolizma, Klinički centar Vojvodine, Novi Sad, Srbija \\ ${ }^{2}$ Medicinski fakultet Novi Sad, Univerzitet u Novom Sadu, Novi Sad, Srbija \\ ${ }^{3}$ Katedra za farmakologiju, toksikologiju i kliničku farmakologiju, Medicinski fakultet Novi Sad, Univerz- \\ itet u Novom Sadu, Novi Sad, Srbija \\ ${ }^{4}$ Departman za biomedicinske nauke, Visoka škola strukovnih studija za obrazovanje vaspitača i trenera, \\ Subotica, Srbija \\ ${ }^{5}$ Centar za sudsku medicinu, toksikologiju i molekularnu genetiku, Klinički centar Vojvodine, Novi Sad, \\ Srbija \\ ${ }^{6}$ Katedra za farmaciju, Medicinski fakultet Novi Sad, Univerzitet u Novom Sadu, Novi Sad, Srbija
}

\section{KRATAK SADRŽAJ}

Uvod: Primarna dismenoreja je veoma čest poremećaj kod žena, uz veliki uticaj na kvalitet života.

Cilj: Cilj ovog istraživanja bio je određivanje težine tegoba dismenoreje kod studentkinja Medicinskog fakulteta u Novom Sadu; sticanje uvida u učestalost samomedikacije primarne dismenoreje; identifikovanje najčešće upotrebljenih konvencionalnih, biljnih i homeopatskih lekova, kao i načina njihove upotrebe, te nefarmakoloških mera u tretmanu primarne dismenoreje.

Metodologija: Istraživanje je sprovedeno na slučajnom uzorku od 100 ispitanica različitih studijskih grupa Medicinskog fakulteta u Novom Sadu, u periodu od 1.12.2016. do 15.12.2016. Podaci su dobijeni pomoću standardizovanog upitnika.

Rezultati: Uzorak je obuhvatio 59 studentkinja medicine i 41 studentkinju ostalih studijskih grupa. Većina ispitanica je imala srednje izražene tegobe dismenoreje $(48.0 \%)$. Najizraženije tegobe bile su grčevi i bol u donjem delu trbuha, nervoza $i$ promene apetita. Usled dismenoreje, čak $11 \%$ ispitanica izostaje sa nastave na fakultetu minimum jedan dan svakog ciklusa. Lekove je usled tegoba dismenoreje uzimalo $66.0 \%$ ispitanica. Najčešće korišćena grupa lekova bili su nesteroidni antiinflamatorni lekovi (75.76\%), i to ibuprofen (53.03\%) i diklofenak (10.61\%). Učestalost samomedikacije bila je $48.48 \%$.

Zaključak: Na osnovu rezultata ovog istraživanja, možemo zaključiti da dismenoreja značajno utiče na kvalitet života studentkinja.

Ključne reči: menstrualni bol, nesteroidni antiinflamatorni lekovi, studentkinje medicinskog fakulteta 